\title{
Apelin-13 increased food intake with serum ghrelin and leptin levels in male rats
}

\author{
Saral $\mathrm{S}^{1}$, Alkanat $\mathrm{M}^{2}$, Sumer $\mathrm{A}^{3}$, Canpolat $\mathrm{S}^{4}$ \\ Recep Tayyip Erdogan University, Medicine Faculty, Department of Physiology, Rize, Turkey. \\ sinansaral61@msn.com
}

\section{ABSTRACT}

In this study, we aimed to explain the role of apelin-13 on body weight, food and water intake with serum leptin, ghrelin, neuropeptid Y (NPY) and peptid YY (PYY) levels in male rat. Thirty-two Sprague-Dawley male rats were used for the study. The rats were injected SP (0.9\%) intraperitoneally (i.p) in the control group and 30 (AP30), 100 (AP100) and 300 (AP300) $\mu \mathrm{g} / \mathrm{kg}$ apelin-13 in the study groups, respectively, 10 min before the transition to dark period, for 10 days. During the experimental period, with light and dark periods of food and water intake, body weights were recorded in rats. Rats were euthanized and serum samples were obtained. In serum samples leptin, ghrelin, NPY and PYY levels were measured with specific ELISA kit. Apelin-13 was increased body weights in all three (AP30, AP100 and AP300) groups compared with the control group. AP100 and AP300 groups had increased food intake in the dark and the cumulative period, but in the light period food intake values were not significantly increased $(p>0.05)$. As for the value of water intake, compared with the control group, all dose of apelin-13 increased water intake during the dark and the cumulative period. There was no significant change in water intake in the light period. On the other hand, compared with the control group, serum leptin levels were found to increase in the groups administered 100 and $300 \mu \mathrm{g} / \mathrm{kg}$ of apelin-13 $(p<0.05)$. Ghrelin levels were found high in all groups treated with apelin-13. Serum levels of NPY decreased only in the $300 \mu \mathrm{g} / \mathrm{kg}$ apelin-13 treated group $(p<0.05)$. There was no statistically significant change in levels of PYY ( $p>0.05)$. Apelin-13 increases body weight in rats as well as food and water intake (dark and cumulative period). Additionally, ghrelin can mediate the orexigenic effect of apelin-13 in the regulation of food intake (Fig. 4, Ref. 37). Text in PDF www.elis.sk.

KEY WORDS: apelin-13, food intake, ghrelin, leptin, neuropeptid Y.

\section{Introduction}

Apelin has been identified as the endogenous ligand of the G-protein-coupled apelin receptor (APJ) (1). APJ remained an "orphan" receptor until the discovery of apelin and was identified from human genomic DNA in 1993 (2). Also, apelin-13 has been reported to be synthesized by adipose tissue (3) and pyroglutamated apelin-13 originates from 77 amino acid pre-propeptide precursor $(4,5)$. Hydrophobic residues of apelin-13 play important roles in interaction with APJ receptor because they are considered to be physiologically relevant $(6,7)$.

Apelin and APJ receptor show a widespread distribution in the central and peripheral tissues of humans and rodents. Although APJ mRNA is found in many central regions, it is also found in the pituitary gland, pineal gland, as well as hypothalamic para-

${ }^{1}$ Recep Tayyip Erdogan University, Medicine Faculty, Department of Physiology, Rize, Turkey, ${ }^{2}$ Giresun University, Medicine Faculty, Department of Physiology, Giresun, Turkey, ${ }^{3}$ Recep Tayyip Erdogan University, Healthy Science School, Rize, Turkey, and ${ }^{4}$ Firat University, Medicine Faculty, Department of Physiology, Elazig, Turkey

Address for correspondence: S. Saral, Recep Tayyip Erdogan University, Medicine Faculty, Department of Physiology, 53000, Rize, Turkey Phone: +90.464 .3442045$

Acknowledgement: This project was supported by Karadeniz Technical University (KTU) scientific research Project Unit (Praje No 1024). ventricular nucleus (PVN), arcuate nucleus (ARN) and supraoptic nucleus ( $\mathrm{SON}$ ) that regulate the food intake, water metabolism and energy homeostasis $(8,9)$. In addition, immunohistochemical studies showed that apelin positive cells appeared in human and rat's gastric epithelium mucosa of the stomach. Similarly, lower concentration of apelin mRNA expression is found in duodenum, jejunum, ileum and colon (10).

The apelin/APJ localization in the regions having a role in the central and peripheral regulation of food intake suggests that apelin may play an important role in the regulation of food intake and energy homeostasis. Nonetheless, different results were obtained in the studies reporting that apelin suppressed $(11,12)$, increased $(13,14,15)$ or did not change food intake (6). These results show that the role of apelin in the regulation of feeding behavior is not clear yet. On the other hand, plasma apelin level was increased in obese experimental animals and obese human $(3,16)$. This data suggested that the effect of apelin on food intake may be related to the other leptin-like endocrine peptides of adipose tissue. Apelin stimulates cholecystokin (CCK) release through mitogen-activated protein kinase (MAPK) and in vitro cell proliferation in gastric cells enteroendocrine cell lines (10). Similarly, Flemström et al showed that intra-arterial apelin-13 infusion stimulates bicarbonate secretion in duodenum (17). In addition, apelin-12 elevates gastric acid secretion by stimulating histamine release in gastric mucosa in rats (18). 
It is known that gastrointestinal exocrine and endocrine secretion hasa pivotal role in the control of appetite and feeding. The oxyntic mucosa of the stomach which is the main source of ghrelin (19) also synthesizes apelin (20). However, the relationship between apelin and ghrelin is unknown in the regulation of food intake. On the other hand, L cells of the gastrointestinal tract synthesize Peptid YY (PYY) in response to food consumption from ileum and colon has no information for the interaction between apelin. We hypothesized that apelin may exert an orexigenic effect by increasing ghrelin synthesis and release. Therefore, this study evaluated the chronic peripheral administration of apelin-13 effects on food intake and body weight with serum ghrelin, leptin and PYY level in male rats.

\section{Materials and methods}

\section{Animals and procedures}

The protocol of the study was approved by Karadeniz Technical University, Local Ethics Committee for Animal Experiments (protocol 2010/42). In this study, 32 Sprague Dawley male rats weighing 180-220 g were used and they were obtained from the Karadeniz Technical University Faculty of Medicine Surgical Research Centre. The animals were randomly divided into 4 groups, each of 8 rats $(n=8)$ and were placed in metabolic cages (Tecniplast Company, Italy) for 5 days before the experiments due to habituation. All animals were kept in artificially controlled cages regarding light $(12 / 12 \mathrm{~h}$ light and dark $)$, temperature $\left(22 \pm 2{ }^{\circ} \mathrm{C}\right)$ and humidity $(55 \pm 5 \%)$. Standard rat chow (Bayramoğlu Feed Factory / Erzurum, Turkey) was used for daily feeding of the rats. Daily feeding amount and body weight ratio of the rats in metabolic cages were monitored and measured. Similarly, scaled drinking bowls of the metabolic cages were used for fresh tap water and the rats were provided with ad-libitum access to feed.

\section{Study groups}

Apelin-13 isoform was selected in the present study. Apelin-13 (Bachem, Switzerland) with higher biological activity and receptor

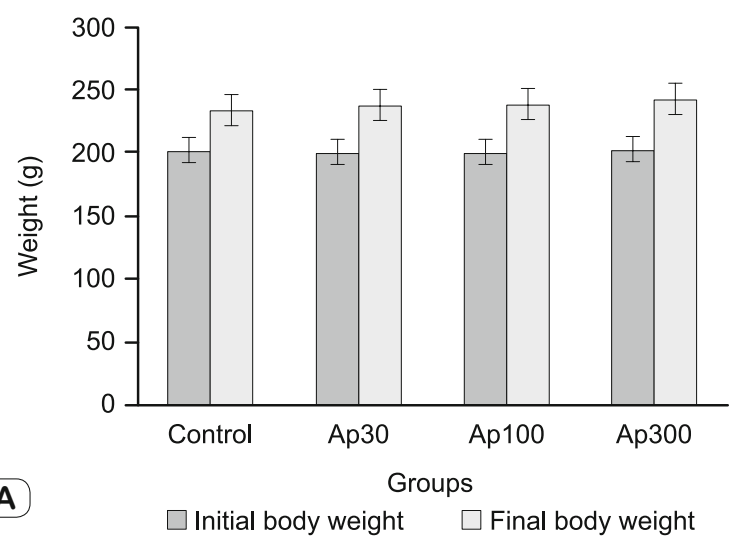

affinity among apelin isoforms was used in the study $(8,21)$. The rats in the group 1(control) were injected intraperitoneally (i.p) with isotonic saline solution (SFN and CIS vehicle), in the group 2 (AP30), apelin-13 was dissolved in isotonic saline solution daily and administered to rats with an intraperitoneal injection $(30 \mu \mathrm{g} /$ $\mathrm{kg}$ ), group 3 (AP100) was injected intraperitoneally at a dose of $100 \mu \mathrm{g} / \mathrm{kg}$ apelin-13 and group 4 (AP300) was injected intraperitoneally witha dose of $300 \mu \mathrm{g} / \mathrm{kg}$ of apelin-13.

\section{Body weight, food and water intake measurements}

After 5 days of habituation, body weight, food and water intake were recorded at the begging of the experiments. All metabolic data sets were recorded every day 2 times in the initial period. Measurements were recorded at the end of light phase (07:00-19:00) and dark phase (19:00-07:00). Vehicle and drug administration were applied before transition of the dark phases. Room light source of 5152 lux was used to create normal daylight lighting conditions (5000 lux). Feeder was filled up with50 gr pellet feed and according to consumption remaining pellet feed was changed for fresh pellets. Similarly, drinking bowl was filled with fresh tap water every day after the measurements. Baseline body weight of the rats was determined as $100 \%$ and the results were shown as $\%$.

\section{Biochemical analyses}

Rats were sacrificed 10 minutes after the last injection. Blood samples were collected in to blood tubes containing aprotinin at the end of the experiment. Serum samples were kept at $-80^{\circ} \mathrm{C}$ until the analyses. Serum Leptin (BioVendor, Catalog No. RD291001200, Czech Republic), PYY (Phoenix Pharmaceuticals, Catalog No. EK-059-03, USA), NPY (Phoenix Pharmaceuticals, Catalog No. EK-049-03, USA) and ghrelin (Phoenix Pharmaceuticals, Catalog No. EK-031-31, USA) levels were determined using ELISA kits.

\section{Statistical analysis}

All statistical analyses were performed using the software package SPSS 22.0 (IBM SPSS Inc, Chicago, IL, USA). Firstly, compliance of variances to normal distribution was evaluated with

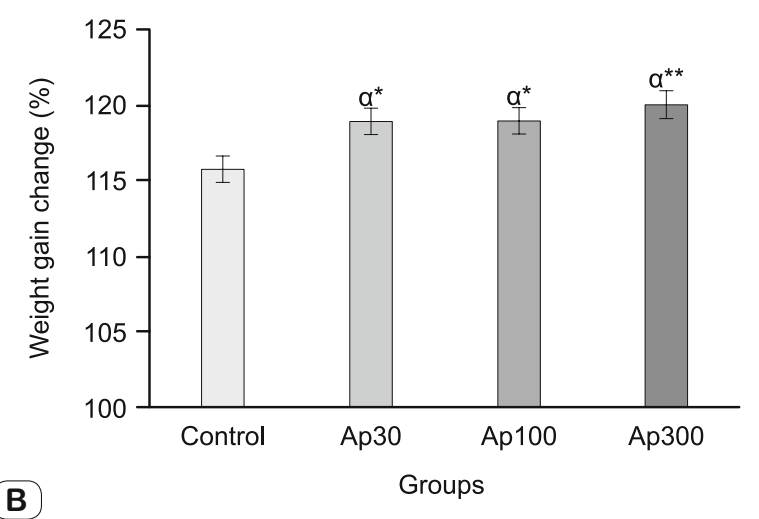

Fig. 1. The results of initial and final body weight (A) and \% body weight change of rat (B) after injection of apelin-13 (30, 100 and $300 \mu g / k g)$ and saline (control) on body weight in Sprague Dawley male rats. All data are presented as mean $\pm \mathrm{S}$.E.M. for $\mathbf{n}=8 / \mathrm{group}$. $\alpha$ : control-AP30, $\beta$ : control-AP100, $\gamma$ : control-AP300. ${ }^{*} p<0.05$ and $* * p<0.01$. Baseline body weight of the rats was determined as $100 \%$ and the results were shown as \% changes in live body weight during the experiment. 
Kolmogorov-Smirnov (KS) test. Whether the variances were compliant with homogenous distribution was determined by Levene statistic (LS). Post-hoc Dunnett's test was used for the comparison of apelin-13 treated groups to the control group.

Mann-Whitney-U test was used for the evaluation of biochemical measurements. The significance value of $\mathrm{p}<0.05$ was accepted in statistical analyzes. All data were presented as mean \pm SEM.

\section{Results}

Effect of chronic i.p. apelin-13 on body weight in ad-libitum feeding rat during experimental period

Apelin-13 increased the body weight compared to the control group in all three dosages (30, 100 and $300 \mu \mathrm{g} / \mathrm{kg} / \mathrm{rat}$ i.p.). An independent sampling comparison among the groups revealed statistically significant increases in the rats body weight gaining ratios of the AP30 (p<0.05), AP100 (p<0.05) and AP300 (p < 0.01 ) groups compared to the control (Fig. 1A,B).

Effect of chronic i.p. apelin-13 on light, dark and cumulative periods (24-hour) on food intake in ad-libitum fed rat

In the light period measurement, no changes were observed in food intake of three groups compared to the control group, following apelin-13 (30, 100 and $300 \mu \mathrm{g} / \mathrm{kg} / \mathrm{rat}$, i.p.) administration $(p>0.05)$ (Fig. 2A). In the dark period of measurement, the administration of $30 \mu \mathrm{g} / \mathrm{kg}$ apelin-13 did not alter the food intake compared to the control group ( $p>0.05$ ) (Fig. 2B). However, the administration of 100 and $300 \mu \mathrm{g} / \mathrm{kg}$ of apelin-13 increased food intake ( $<$ 0.001) (Fig. 2B). Similarly, while in the cumulatively period, $30 \mu \mathrm{g} / \mathrm{kg}$ apelin-13 administration did not change the food intake, 100 and $300 \mu \mathrm{g} / \mathrm{kg}$ dose of apelin-13 increased the food intake compared to the control group ( $<<0.001)$ (Fig. $2 \mathrm{C})$.

Effect of chronic i.p. apelin-13 on light, dark and cumulative periods (24-hour) on water intake in ad-libitum fed rat

In the light period of the measurement, no changes were observed in water intake of the three groups compared to the control group, following apelin-13 (30, 100 and $300 \mu \mathrm{g} / \mathrm{kg} / \mathrm{rat}$, i.p. ) administration ( $p>0.05)$ (Fig. 3A). However, for the dark and cumulative period measurements, all doses of apelin-13 increased water intake compared to the rats in the control group ( $\mathrm{p} \leq 0.001)$ (Fig. 3B,C).

\section{Biochemical results}

It was seen that the serum leptin levels in the AP100 (2239 \pm $19 \mathrm{pg} / \mathrm{ml}, \mathrm{p}<0.05)$ and AP300 $(1906 \pm 10 \mathrm{pg} / \mathrm{ml}, \mathrm{p}<0.05)$ groups increased considerably in comparison with the control group (Fig. 4A). There was no statistically significant difference in the leptin levels of AP30 group $(1856 \pm 16 \mathrm{pg} / \mathrm{ml})$ in comparison with the control group $(1493 \pm 30 \mathrm{pg} / \mathrm{ml})(\mathrm{p}>0.05)$.

It was observed that the serum ghrelin levels of AP30 (18.38 $\pm 0.95 \mathrm{ng} / \mathrm{ml}), \operatorname{AP} 100(17.23 \pm 1.32 \mathrm{ng} / \mathrm{ml})$ and AP300 $(\mathrm{n}=8$, $19.20 \pm 1.0 \mathrm{ng} / \mathrm{ml}$ ) groups increased remarkably in comparison with the control group $(13.86 \pm 0.99 \mathrm{ng} / \mathrm{ml})$ (respectively, $\mathrm{p}<$ $0.05, \mathrm{p}<0.01$ ) (Fig. 4B).

A statistically significant decrease was observed in the serum
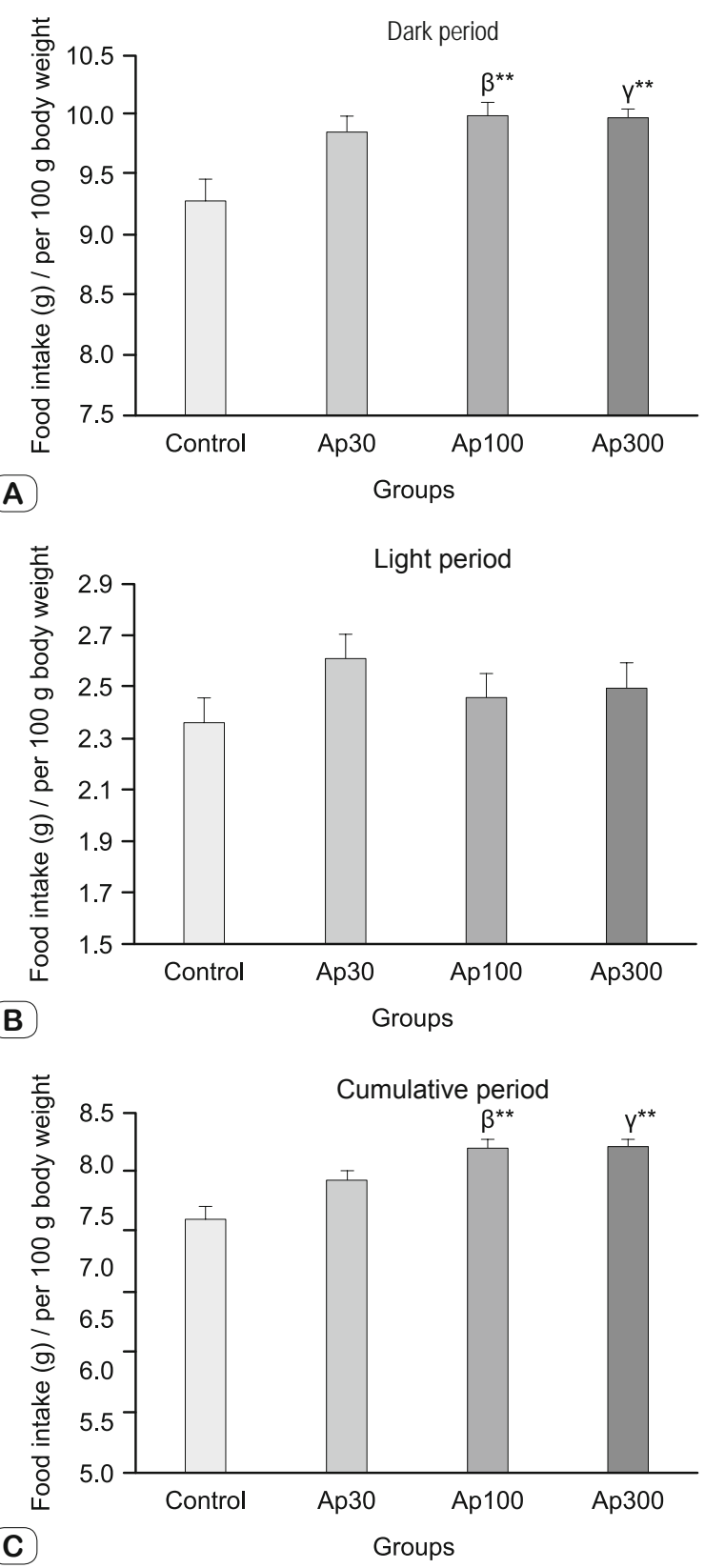

Fig. 2. The result of apelin-13 on light, dark and cumulative period food intake in male rat. Apelin-13 (30, 100 and $300 \mu \mathrm{g} / \mathrm{kg})$ or saline (control) was administration i.p. at the onset of the dark period. All data are presented as mean \pm S.E.M. for $n=8$ /group. $\alpha$ : control-AP30, $\beta$ : control-AP100, $\gamma$ : control-AP300, ${ }^{* *} \mathbf{p}<\mathbf{0 . 0 0 1}$. A. The average food intake values in dark period. $B$. The average food intake values in light period. $C$. The average food intake values in cumulative period $(24 \mathrm{~h})$.

NPY levels of AP300 $(12.59 \pm 1.05 \mathrm{ng} / \mathrm{ml})$ group in comparison with the control group $(\mathrm{p}<0.05)$ (Fig. 4C). There were no statistically important differences in the serum NPY levels of AP30 (16.54 $\pm 1.55 \mathrm{ng} / \mathrm{ml})$ and AP100 $(15.43 \pm 0.67 \mathrm{ng} / \mathrm{ml})$ in comparison with the control group $(17.05 \pm 1.28 \mathrm{ng} / \mathrm{ml})(\mathrm{p}>0.05)$. There were no statistically significant differences in the serum PYY levels of AP30 $(1.60 \pm 0.17 \mathrm{ng} / \mathrm{ml}), \mathrm{AP} 100(1.82 \pm 0.34 \mathrm{ng} / \mathrm{ml})$ and AP300 

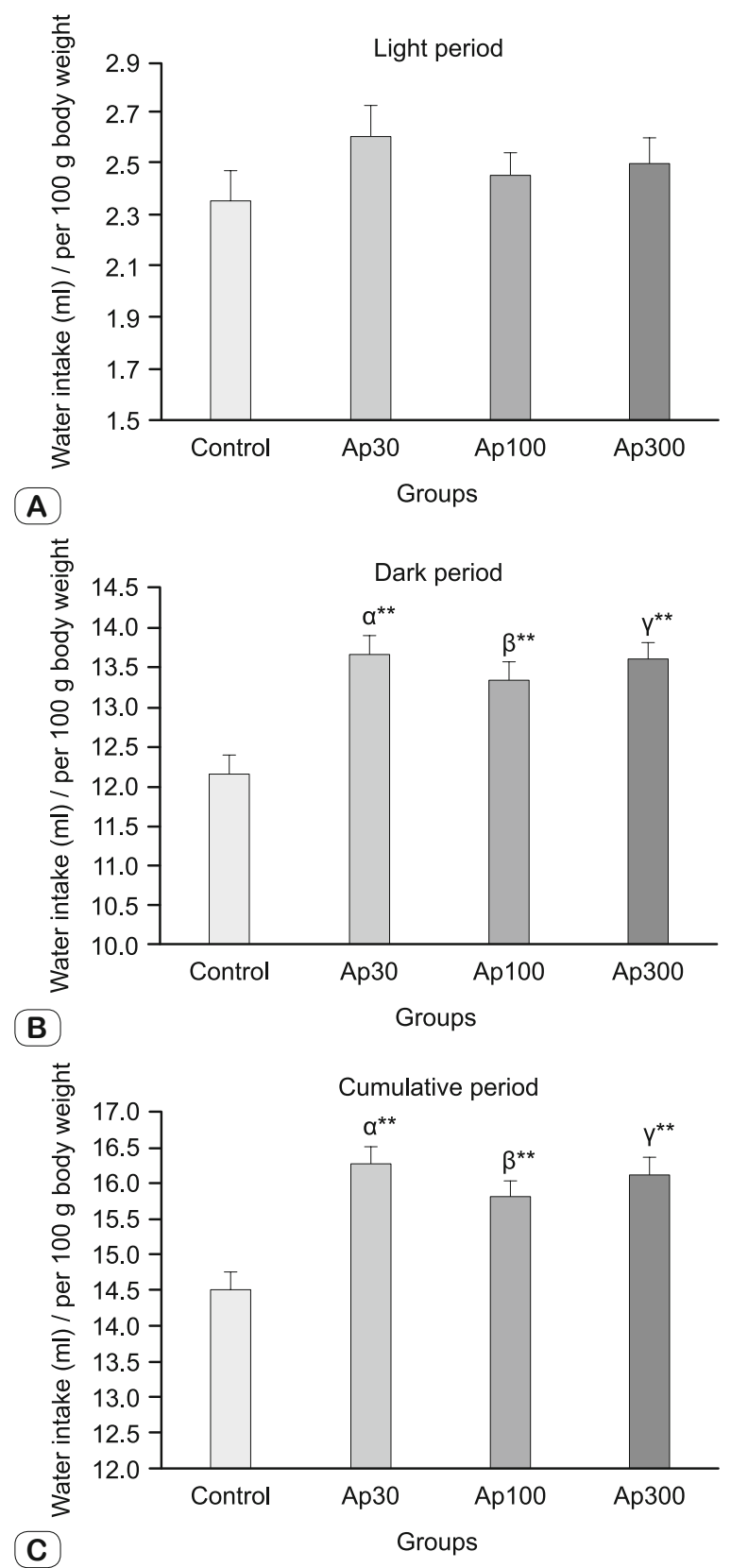

Fig. 3. The results of chronic apelin-13 on light, dark and cumulative water intake in male rat. Apelin-13 (30, 100 and $300 \mu \mathrm{g} / \mathrm{kg})$ or saline (control) was administered i.p. at the onset of the dark period. All data are presented as mean \pm S.E.M. for $n=8$ /group. $\alpha$ : control-AP30, $\beta$ : control-AP100, $\gamma$ : control-AP300, $*$ * $\mathbf{p} \leq \mathbf{0 . 0 0 1}$. A. The average water intake values in light period. $B$. The average water intake values in dark period. $C$. The average water intake values in cumulative period $(24 \mathrm{~h})$.

$(2.03 \pm 0.18 \mathrm{ng} / \mathrm{ml})$ groups in comparison with the control group $(1.93 \pm 0.30 \mathrm{ng} / \mathrm{ml})(\mathrm{p}>0.05)$ (Fig. 4D).

\section{Discussion}

Obesity increases the risk of metabolic and cardiovascular diseases, which may lead to serious health problems and shorten the

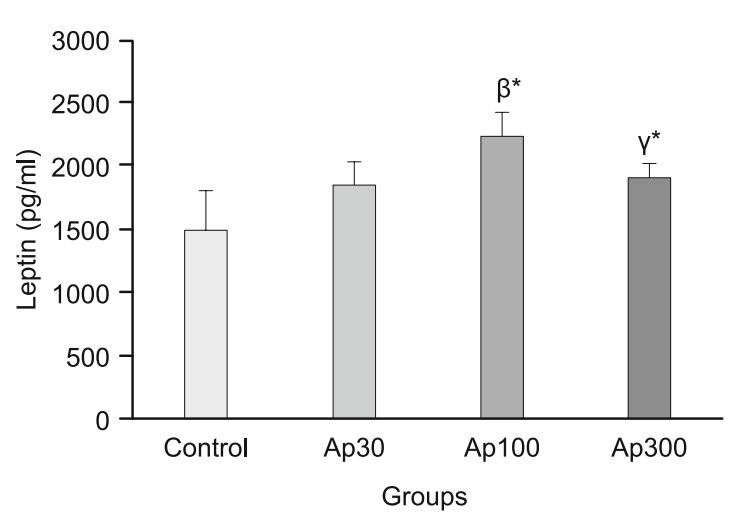

Fig. 4A. Serum leptin levels in groups. Effect of chronic (10 days) i.p. apelin-13 $(30,100$ and $300 \mu \mathrm{g} / \mathrm{kg})$ or saline injection on serum leptin levels in male rats. All data are presented as mean \pm S.E.M. for $\mathbf{n}=8$ / group. $\alpha$ : control-AP30, $\beta$ : control-AP100, $\gamma$ : control-AP300. * $p<0.05$.

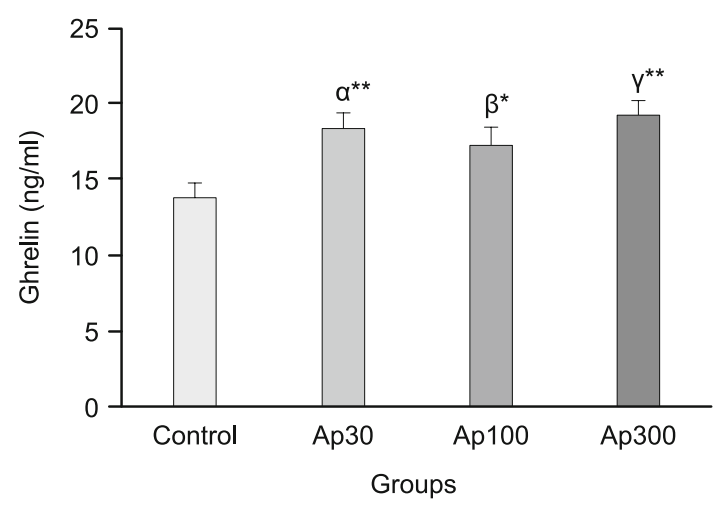

Fig. 4B. Serum ghrelin levels in groups. Effect of chronic (10 days) i.p. apelin-13 (30,100 and $300 \mu \mathrm{g} / \mathrm{kg})$ or saline injection on serum ghrelin levels in male rats. All data are presented as mean \pm S.E.M. for $\mathbf{n}=$ 8/group. $\alpha$ : control-AP30, $\beta$ : control-AP100, $\gamma$ : control-AP300. * $\mathrm{p}<$ 0.05 and $* * \mathrm{p}<0.01$.

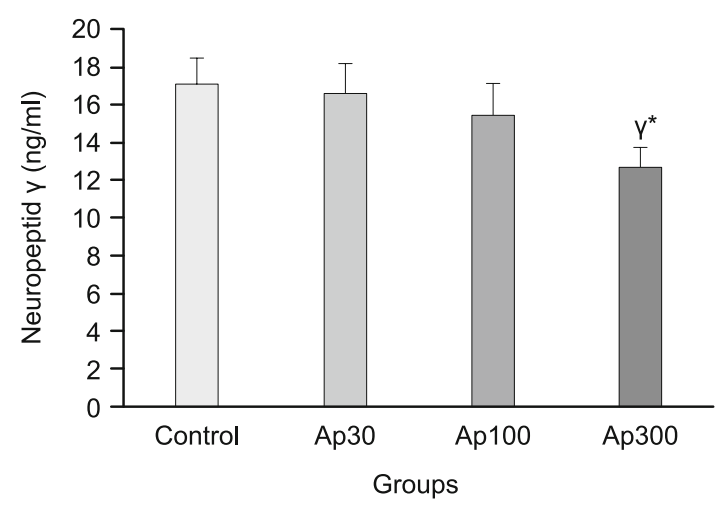

Fig. 4C. Serum NPY levels in groups. Effect of chronic (10 days) i.p. apelin-13 $(30,100$ and $300 \mu \mathrm{g} / \mathrm{kg})$ or saline injection on serum NPY levels in male rats. All data are presented as mean \pm S.E.M. for $\mathbf{n}=8$ / group. $\alpha$ : control-AP30, $\beta$ : control-AP100, $\gamma$ : control-AP300. ${ }^{*} p<0.05$. 


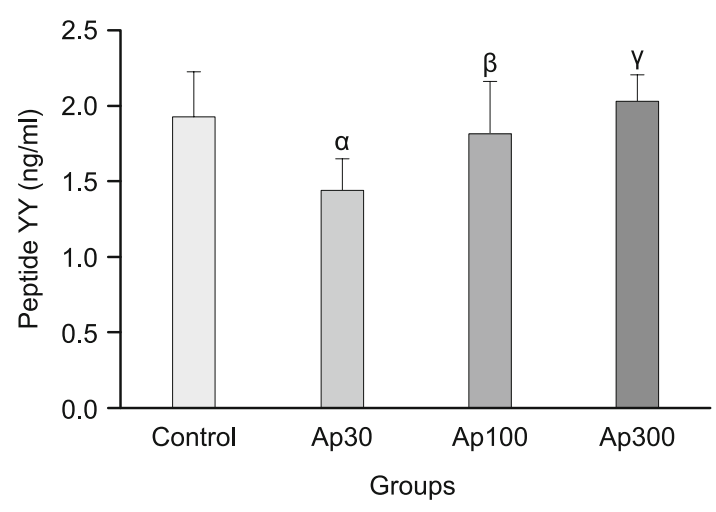

Fig. 4D. Serum PYY levels in groups. Effect of chronic (10 days) i.p. apelin-13 $(30,100$ and $300 \mu \mathrm{g} / \mathrm{kg})$ or saline injection on serum PYY levels in male rats. All data are presented as mean \pm S.E.M. for $\mathbf{n}=8$ / group. $\alpha$ : control-AP30, $\beta$ : control-AP100, $\gamma$ : control-AP300.

lifetime. Adipokines are novel pharmacological agents and they may be used as potential for future pharmacological treatment strategies to modulate feeding behavior and against obesity. It is clear that apelin is synthesized by peripheral tissues $(3,20)$ just like leptin and ghrelin which regulate food intake in adipose tissue and oxyntic mucosa of the stomach, respectively. Furthermore, apelin and its receptor APJ are widely spread in central nervous system, especially ARN, PVN and SON which regulates energy balance and homeostasis of feeding behavior (22). This study could be helpful in describing the feeding behavior of apelin and investigatingthe relationship known to be effective in the peripheral and central nervous system on food intake; leptin, ghrelin, NPY and PYY levels.

In this study, the body weight values of male rats were examined after chronic administration of intraperitoneal apelin-13. Adminestered apelin-13 (30,100 and $300 \mu \mathrm{g} / \mathrm{kg})$ increaesed the body weight compared to control. Valle et al (13) showed that chronic central administration of apelin-13 increased body weight, locomotor activity and body temperature in C57BL/6 mice. Tekin et al (14) reported that chronic apelin-13 increased rats food intake and body weight, and the study showed the orexigenic effect of apelin-13.

In the literature, there are highly controversial results about apelin and food intake. O'Shea et al found that lateral cerebral ventricular injection of $10 \mathrm{nmol}$ apelin-12 stimulated food intake during the day but suppressed food intake at night (23). Another a study showed that 1 and $3 \mu \mathrm{g} /$ mouse of apelin-13 injection cumulatively reduced food intake at $4 \mathrm{~h}$ after treatment (12). The present study showed that long term apelin-13 administration (30, 100 and $300 \mu \mathrm{g} / \mathrm{kg}$, respectively) elevated water and food intake in the dark period compared the control groups $(\mathrm{p}<0.001)$ (Fig. 2B,C). Also, Taheri et al (24) reported that an apelin-13 dose dependently increases food intake at $2-4 \mathrm{~h}$ after the administration in fasted rats. However, some studies reported i.c.v administration of apelin-13 decreases food intake in animal models (11, 25). Reaux-Le Goanzigo et al (26) revealed that K17F, a known active apelin fragment levels are elevated in POMC neurons of
ARN leads to $\alpha$-MSH release in an autocrine manner decreasing the food intake while R10F inactive form of apelin has not generated this effect.

It could be a well-known effect of apelin/apj receptor that has been subjected on water intake. The central mRNA expression of preproapelin in the regions of the hipocampus, hypothalamus, thalamus and midbrain shares a distribution pattern similar to that of angiotensinogen. Lee et al indicated that intraperitoneally administered apelin increased water intake after 30 minutes of the injection and this effect reverted to the basal level in an hour. (27). Taheri et al (24) reported that apelin-13 increased water intake by up to six fold compared to saline. Apelin has a role in the regulation of the hypothalamopituitary - adrenal (HPA) axis. This action is mediated through the activation of AVP and/or CRF release. Apelin-13 stimulated CRF and AVP release (24). On the contrary to other studies, apelin has been reported to reduce water intake after i.c.v. injection (9) or to have no effects (28). Our study results show that all apelin administrated groups significantly increased water intake compared to the control group (Fig. 3B,C). However, increased water intake in apelin administrated group could be a consequence of elevation of food intake and body weight due to increased requirements as inevitable results.

The adipokine leptin inhibits NPY and agouti-related peptide (AgRP) neuronal activity resulted in decreased food intake (29, 30). Leptin is synthesized from adipose tissue as a response to high fat diet (31). In this study, a significant increase in serum leptin levels was observed at doses of 100 and $300 \mu \mathrm{g} / \mathrm{kg}$ apelin-13 compared to control group. Even though this is not the primary aim of this study, long-term apelin administrations induced not only body weigth gain, but also it could increase adipose tissue mass. Thus, it was speculated that leptin production stimulated the compensatory mechanisms. Also decreased serum NPY level was observed in $300 \mu \mathrm{g} / \mathrm{kg}$ group as a consequence of elevated leptin levels (Fig. 4A,C). Schwartz et al (32) reported that leptin administration reduces NPY gene transcription in ARN. Similarly, leptin suppresses NPY/AGRP neurons while stimulating POMC neurons in hypothalamic ARN (33). This results in a feeling of satiety and a decrease in food intake. In our study, increased leptin levels seemed to be a possible consequence of suppressing NPY synthesis and release. Apelin not only affects the central nervous system, it also shows activity in the gastrointestinal tract. Wang et al showed that apelin stimulates the gastric cell proliferation and also stimulates CCK secretion by mitogen-activated protein kinase (10). Another study demostrated that intravenous apelin administrations stimulate and elevate gastric acid secretion in rats (18). The studies show that apelin interacts with orexigenic and/ or anorexigenic factors of the gastrointestinal tract considering energy metabolism and feeding regulation.

In the literature, there are no reports on the effects of apelin administration on ghrelin synthesis and release from experiments. Wren et al (34) have reported that both central and peripheral ghrelin administration have increased food intake in rats. NPY and Agouti-related peptide (AgRP) neurons located in ARN have been previously reported to be one of the mechanisms mediating the effect of ghrelin in stimulating food intake in rats (35). 
Our results showed that ghrelin levels were elevated in apelin administered groups (AP30, AP100 p $<0.05$, AP300 p $<0.01$, compared with control group, respectively Fig. 4B). However, in the present study, it was observed that NPY levels decreased in the group treated with $300 \mu \mathrm{g} / \mathrm{kg}$ apelin-13. Taheri et al (24) have reported that NPY release remains unchanged in hypothalamic tissue of the rats that were given of apelin-13 in vitro. In addition, apelin mRNA receptor assays performed at a central level in rats displayed that immunoreactive neuronal cell bodies of apelin could be detected in about $5 \%$ of the neuronal areas expressing NPY especially located in ARN (26). These results suggest that non-NPY pathways may be involved in the orexigenic effect of apelin. On the other hand, another way ofmediating orexigenic effect of ghrelin are orexin neurons in lateral hypothalamic area. Ghrelin induces an orexigenic effect by increasing depolarization and action potential frequency in orexin neurons (36). In a current report, intrahypothalamic administration of apelin-13 (1-2 $\mu \mathrm{g} / \mathrm{rat})$ has orexigenic effects which are mediated by increased orexin-A. Additionally, both serotonin (5-hydroxytryptamine, 5-HT) synthesis and cocaine- and amphetamine-regulated transcript (CART) gene expression are decreased in male rats (15). These results support the hypothesis that the orexigenic effect of apelin may be mediated by orexin-A neurons. This study also examined the effect of chronic peripheral apelin-13 on serum PYY levels. PYY is an anorexogenic peptide released primarily by L-cells in ileum and colon leading to reduced energy intake and body weight (37). In the present study, administered apelin-13 had no effect on serum PYR levels ( $p>0.05)$ (Fig. 4D). This result was not in contradiction with the food intake values. However, there were insufficient data to account for the effect of apelin-13 on PYY synthesis and release.

This study demonstrated that ghrelin levels were elevated in all apelin administered groups compared to control. This study and other literature results demonstrated that apelin reveals different results by form, acute/chronic administration, route and dose despite increased or decreased food intake. In this sense, it could be related to other modulators of energy metabolism, which is a more appropriate explanation. In conclusion, food and water intake is connected with biochemical responses to chronic peripheral administration of apelin-13, which was a current adipokine in this study. Our findings have shown that apelin-13 has resulted in orexigenic modulation and mainly the hormone ghrelin could mediate the development of this effect. Therefore, the use of apelin-13 antagonists could be important in the pharmacological treatment of obesity.

\section{Learning points}

Apelin-13 has resulted in orexigenic modulation and mainly the hormone ghrelin could mediate in the development of this effect.

The use of apelin-13 antagonists may be important in the pharmacological treatment of obesity.

Apelin-13 increased body weight in rats as well as food and water intake.

\section{References}

1. Kartal H, Comu FM, Kucuk A, Polat Y, Dursun AD, Arslan M. Effect of apelin-13 on erythrocyte deformability during ischaemia-reperfusion injury of heart in diabetic rats. Bratisl Med J 2017; 118 (3): 133-136.

2. Akcilar R, Ayada C, Turgut G, Turgut S. Supplementation of apelin increase plasma levels of nesfatin-1 in normal and DOCA-salt hypertensive rats. Bratisl Lek Listy 2015; 116 (2): 104-108.

3. Boucher J, Masri B, Daviaud D, Gesta S, Guigné C, Mazzucotelli A, Castan- Laurell I, Tack I, Knibiehler B, Carpéné C, Audigier Y, Saulnier-Blache JS, Valet P. Apelin, a newly identified adipokine up-regulated by insulin and obesity. Endocrinology 2005; 146: $1764-1771$.

4. Tatemoto K, Takayama K, Zou MX, Kumaki I, Zhang W, Kumano K, Fujimiya M. The novel peptide apelin lowers blood pressure via a nitric oxide-dependent mechanism. Regul Pept 2001; 99: 87-92.

5. Kawamata Y, Habata Y, Fukusumi S, Hosoya M, Fujii R, Hinuma S, Nishizawa N, Kitada C, Onda H, Nishimura O, Fujino M. Molecular properties of apelin: tissue distribution and receptor binding. Biochim Biophys Acta 2001; 1538: 162-171.

6. Higuchi K, Masaki T, Gotoh K, Chiba S, Katsuragi I, Tanaka K, Kakuma T, Yoshimatsu H. Apelin, an APJ receptor ligand, regulates body adiposity and favors the messenger ribonucleic acid expression of uncoupling proteins in mice. Endocrinology 2007; 148: 2690-2697.

7. Fan X, Zhou N, Zhang X, Mukhtar M, Lu Z, Fang J, DuBois GC, Pomerantz RJ. Structural and functional study of the apelin-13 peptide, an endogenous ligand of the HIV-1 coreceptor, APJ. Biochemistry 2003; 42: 10163-10168.

8. De Mota N, Lenkei Z, Llorens CC. Cloning, pharmacological characterization and brain distribution of the rat apelin receptor. Neuroendocrinology 2000; 72: 400-407.

9. Reaux A, Gallatz K, Palkovits M, Llorens-Cortes C. Distribution of apelin- synthesizing neurons in the adult rat brain. Neuroscience 2002; 113: 653-662.

10. Wang G, Anini Y, Wei W, Qi X, OCarroll AM, Mochizuki T, Wang HQ, Hellmich MR, Englander EW, Greeley GH Jr. Apelin, a new enteric peptide: localization in the gastrointestinal tract, ontogeny, and stimulation of gastric cell proliferation and of cholecystokinin secretion. Endocrinology 2004; 145: 1342-1348.

11. Sunter D, Hewson AK, Dickson SL. Intracerebroventricular injection of apelin-13 reduces food intake in the rat. Neurosc1 Lett 2003; 353: 1-4.

12. SY Lv, YJ Yang, YJ Qin, Mo JR, Wang NB, Wang YJ, Chen Q. Central apelin-13 inhibits food intake via the CRF receptor in mice. Peptides 2012; 33: 132-138.

13. Valle A, Hoggard N, Adams AC, Roca P and Speakman JR. Chronic central administration of apelin-13 over 10 days increases food intake, body weight, locomotor activity and body temperature in C57BL/6 mice. J Neuroendocrinol 2008; 20: 79 -84.

14. Tekin S, Erden Y, Sandal S, Etem Onalan E, Ozyalin F, Ozen H, Yilmaz B. Effects of apelin on reproductive functions: relationship with feeding behavior and energy metabolism. Arch Physiol Biochem 2017; 123: 9-15.

15. Ferrante C, Orlando G, Recinella L, Leone S, Chiavaroli A, Di Nisio C, Shohreh R, Manippa F, Ricciuti A, Vacca M, Brunetti L. Central apelin-13 administration modulates hypothalamic control of feeding. J Biol Regul Homeost Agents 3: 883-888. 
16. Heinonen MV, Purhonen AK, Miettinen P, Pääkkönen M, Pirinen E, Alhava E, Akerman K, Herzig KH. Apelin, orexin-A and leptin plasma levels in morbid obesity and effect of gastric banding. Regul Pept 2005; 130: 7-13.

17. Flemstrom G, Makela K, Purhonen AK, Sjöblom M, Jedstedt G, Walkowiak J, Herzig KH. Apelin stimulation of duodenal bicarbonate secretion: feding dependent and mediated via apelin-induced release of enteric cholecystokinin. Acta Physiol 2011; 201: 141-150.

18. Ohno S, Yakabi K, Ro S, Ochiai M, Onouchi T, Sakurada T, Takabayashi H, Ishida S, Takayama K. Apelin-12 stimulates acid secretion through an increase of histamine release in rat stomachs. Regul Pept 2012; 174: 71-78.

19. Kojima M, Hosoda H, Date Y, Nakazato M, Matsuo H, Kangawa K. Ghrelin is a growth-hormone-releasing acylated peptide from stomach. Nature 1999; 6762: 656-660.

20. Susaki E, Wang G, Cao G, Wang HQ, Englander EW, Greeley GH Jr. Apelin cells in the rat stomach. Regul Pept 2005; 129: 37-41.

21. Hosoya M, Kawamata Y, Fukusumi S, Fujii R, Habata Y, Hinuma S, Kitada C, Honda S, Kurokawa T, Onda H, Nishimura O, Fujino M. Molecular and functional characteristics of APJ. Tissue distribution of mRNA and interaction with the endogenous ligand apelin. J Biol Chem 275: 21061-21070.

22. Reaux A, De Mota N, Skultetyova I, Lenkei Z, El Messari S, Gallatz K, Corvol P, Palkovits M, Llorens-Cortès C. Physiological role of a novel neuropeptide, apelin, and its receptor in the rat brain. J Neurochem 2001; 77: 1085-1096.

23. O'Shea M, Hansen MJ, Tatemoto K, Morris MJ. Inhibitory effect of apelin-12 on nocturnal food intake in the rat. Nutr Neurosci 2003; 6 : $163-167$.

24. Taheri S, Murphy K, Cohen M, Sujkovic E, Kennedy A, Dhillo W, Dakin C, Sajedi A, Ghatei M, Bloom S. The effects of centrally administered apelin-13 on food intake, water intake and pituitary hormone release in rats. Biochem Biophys Res Commun 2002; 291 : 1208-1212.

25. Clarke KJ, Whitaker KW, Reyes TM. Diminished metabolic responses to centrally-administered apelin-13 in diet-induced obese rats fed a high-fat diet. J Neuroendocrinol 2009; 21: 83-89.
26. Reaux-Le Goazigo A, Bodineau L, De Mota N, Jeandel L, Chartrel N, Knauf C, Raad C, Valet P, Llorens-Cortes C. Apelin and the proopiomelanocortin system: a new regulatory pathway of hypothalamic alpha-MSH release. Am J Physiol Endocrinol Metab 2011; 301: 955-966.

27. Lee DK, Cheng R, Nguyen T, Fan T, Kariyawasam AP, Liu Y, Osmond DH, George SR, O'Dowd BF. Characterization of apelin, the ligand for the APJ receptor. J Neurochem 2000; 74: 34-41.

28. Mitra A, Katovich MJ, Mecca A, Rowland NE. Effects of central and peripheral injections of apelin on fluid intake and cardiovascular parameters in rats. Physiol Behav 2006; 89: 221-225.

29. Elmquist JK, Bjorbaek C, Ahima RS, Flier JS, Saper CB. Distributions of leptin receptor mRNA isoforms in the rat brain. J Comp Neurol 1998; 395: 535-547.

30. Schwartz MW, Woods SC, Porte D Jr, Seeley RJ, Baskin DG. Central nervous system control of food intake. Nature 2000; 404: 661-671.

31. Friedman JM, Halaas JL. Leptin and the regulation of body weight in mammals. Nature 1998; 395: 763-770.

32. Schwartz MW, Erickson JC, Baskin DG, Palmiter RD. Effect of fasting and leptin deficiency on hypothalamic neuropeptide $Y$ gene transcription in vivo revealed by expression of a lacZ reporter gene. Endocrinology 1998; 139: 2629-2635.

33. Baver SB, Hope K, Guyot S, Bjørbaek C, Kaczorowski C, O'Connell KM. Leptin modulates the intrinsic excitability of AgRP/NPY neurons in the arcuate nucleus of the hypothalamus. J Neurosci 2014; 34: 5486-5496.

34. Wren AM, Small CJ, Abbott CR, Dhillo WS, Seal LJ, Cohen MA, Batterham RL, Taheri S, Stanley SA, Ghatei MA, Bloom SR. Ghrelin causes hyperphagia and obesity in rats. Diabetes 2001; 50: 2540-2547.

35. Zigman JM, Jones JE, Lee CE, Saper CB, Elmquist JK. Expression of ghrelin receptor mRNA in the rat and the mouse brain. J Comp Neurol 2006; 494: 528- 548.

36. Yamanaka A, Beuckmann CT, Willie JT, Hara J, Tsujino N, Mieda M, Tominaga M, Yagami Ki, Sugiyama F, Goto K, Yanagisawa M, Sakurai T. Hypothalamic orexin neurons regulate arousal according to energy balance in mice. Neuron 2003; 38: 701-713.

37. Sobrino Crespo C, Perianes Cachero A, Puebla Jiménez L, Barrios V. \& Arilla Ferreiro E. Peptides and food intake. Front Endocrinol 2014; 5: 58.

Received August 8, 2017. Accepted September 2, 2017. 